\title{
Dampak Dispersion Of Ownership, Financial Distress, Dewan Pengawas, Umur Listing terhadap Pengungkapan Sukarela Bank Syariah
}

\author{
Barry Alfian 1 \\ Fakultas Ekonomi dan Bisnis \\ Universitas Mataram, Indonesia \\ Email: barryalfian@yahoo.com
}

\author{
Lilik Handajani ${ }^{2}$ \\ Fakultas Ekonomi dan Bisnis \\ Universitas Mataram, Indonesia
}

\section{Nyoman Nugraha Ardana Putra ${ }^{3}$ \\ Fakultas Ekonomi dan Bisnis \\ Universitas Mataram, Indonesia}

\begin{abstract}
ABSTRAK
Penelitianini bertujuan untuk melihat pengaruh ownership dispersion, financial distress, dewan pengawas syariah dan umur listing terhadap luas pengungka pan sukarela pada bank syariah yang terdaftar di OJK pada periode2015-2018. Populasi penelitian sebanyak 14 perusahaan Bank Umum Syariah (BUS) danjumlah sampel yang dida pat sebanyak 13 perusahaan dengan periode pengamatan selama 4 tahun. Teknik analisis data menggunakan regresi linier berganda. Hasil statistik menunjukkanSecara simultan bahwa dispersion of ownership, financial distress, dewan pengaw as syariah dan umur listing memiliki pengaruh positif dan signifikan terhadap pengungkapan sukarela Bank Umum Syariah. Sementara secara parsial dispersion of ownership dan dewan pengawas syariah pengaruh negatif signifikan terhadap pengungkapan sukarela Bank Umum Syariah (BUS).
\end{abstract}

Kata Kunci: Pengungkapan Sukarela; Ownership Dispersion; Financial Distress; Dewan Pengawas; Umur Listing.

The Impact Of Dispersion Of Ownership, Financial Distress, Supervisors Board, Listing Age On Listing Disclosure Of Sharia Banks

\section{ABSTRACT}

This study aims to look at the effect of ownership dispersion, financial distress, sharia supervisory board and age of listings on the extent of voluntary disclosure in Islamic banks registered with OJK in the 2015-2018 period. The population of the study was 14 companies of Islamic Commercial Banks and the number of samples obtained were 13 companies with an observation period of 4 years. Data analysis techniques using multiple linear regression. Statistical results show that Simultaneous that dispersion of ownership, financial distress, sharia supervisory board and age of listings have a positive and significant effect on voluntary disclosure of Islamic Commercial Banks. While partially dispersion of ownership and sharia supervisory board negative significant influence on voluntary disclosure of Islamic Commercial Banks.

Keywords: $\quad$ Voluntary Disclosure; Ownership Dispersion; Financial Distress; Supervisory Board; Age Of Listing.

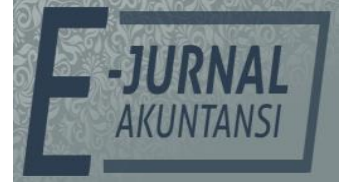

E-JA

e-Jurnal Akuntansi e-ISSN 2302-8556

Vol. 30 No. 6

Denpasar, Juni 2020

Hal.1603-1619

Artikel Masuk:

12 Februari 2020

Tanggal Diterima: 25 Juni 2020

The Article is Available in: https://ojs.unud.ac.id/index.php/Akuntansi/index 


\section{PENDAHULUAN}

Pertumbuhan perbankan syariah di Indonesia tidak terlepas dari mayoritas penduduknya yang beragama islam terbesar di dunia. Hal ini tentunya menjadi pasar yang sangat potensial dalam pengembangan bank syariah. Berdasarkan data Statistik Perbankan Syariah (SPS) yang dikeluarkan oleh Otoritas Jasa Keuangan per Desember tahun 2018 terdapat 14 Bank Umum Syariah dan 20 Unit Usaha Syariah di Indonesia. Pertumbuhan tersebut dapat terlihat dari volume usaha yang terus tumbuh, dana investasi dan dana titipan masyarakat serta penyaluran pembiayaan yang terus meningkat sehingga dapat memberikan kontribusi terhadap aktivitas prekonomian nasional.

Sebagai salah satu lembaga keuangan, bank syariah dituntut untuk menyajikan laporan tahunan seperti halnya pada bank konvensional. Laporan tersebut terbagi atas dua jenis pengungkapan yaitu pengungkapan wajib dan pengungkapan sukarela. Pengungkapan wajib adalah pengungkapan informasi yang diharuskan dalam laporan keuangan yang diatur oleh pemerintah atau badan standar, sedangkan pengungkapan sukarela adalah pengungkapan yang dilakukan perusahaan diluar apa yang diwajibkan oleh standar akuntansi atau peraturan badan pengawas (Suwardjono, 2005).

Standar Akuntansi Keuangan (SAK) mengharuskan lebih banyak pengungkapan dalam laporan keuangan. Pengungkapan dapat berupa kebijakan akuntansi, rincian detail, penjelasan penting, dan komitmen yang terkait dengan manajemen. Sehingga dengan adanya pengungkapan baik wajib maupun sukarela, diharapkan para pengguna laporan keuangan (stakeholder) dapat mempertimbangkan informasi yang relevan terkait dengan peristiwa penting dalam laporan keuangan untuk menilai strategi bisnis manajemen. Selain itu, pengungkapan sukarela juga dapat menjadi informasi tambahan yang dapat meningkatkan kredibilitas perusahaan di mata investor dan kreditur.

Bank syariah menggunakan dua standar dalam penyusunan laporan keuangan. Hal ini menjadi menarik karena sebagai entitas yang memiliki akuntabilitas publik signifikan, bank syariah menggunakan Standar Akuntansi Keuangan (SAK), sedangkan untuk transaksi syariah menggunakan SAK Syariah. Dengan demikian, secara konteks filosofis teori akuntansi syariah menurut Triyuwono (2006:321) adalah prinsip teologikal, dimana akuntansi bukan sekedar bertugas sebagai media pengambilan keputusan ekonomi, tetapi juga memiliki tujuan pertanggung jawaban kepada Tuhan, kepada sesama manusia, dan kepada alam semesta. Hal serupa juga diutarakan oleh Baydoun dan Willet (1994 dalam Triyuwono 2006:325) yang mengatakan bahwa tujuan dasar laporan keuangan akuntansi syariah yang bersifat "materi" adalah untuk pemberian informasi, sedangkan yang bersifat "spirit" adalah bentuk pertanggung jawaban.

Bagi bank syariah, prinsip pengungkapan ini tidak cukup pada pengungkapan wajib saja. Mengambil hukum taklifi, ada lima hukum dalam Islam yaitu wajib, sunah, makruh, haram, dan mubah yang dalam penelitian ini hanya akan mengambil hukum wajib dan Sunnah (Zahrah, 2012). Jika dianalogikan kepada hal pengungkapan dalam akuntansi, seharusnya bank syariah sebagai bank yang menjalankan prinsip syariah tidak hanya memberikan pengungkapan yang bersifat wajib saja, namun juga perlu melakukan 
pengungkapan sukarela. Walaupun memang tidak wajib, sudah seharusnya bank syariah mengungkapkan informasi tambahan demi meningkatkan kepercayaan dari publik. Jika bank syariah mampu membangkitkan kepercayaan publik, maka ia akan lebih mampu berperan dalam mobilisasi dana, meningkatkan investasi, mencipatakan lapangan kerja, membantu keuangan pemerintah dalam mengatasi defisit anggaran dan mempercepat pertumbuhan ekonomi, dimana hal-hal tersebut adalah hal yang saat ini menjadi kebutuhan mendesak bagi negara- negara muslim (Chapra \& Ahmed, 2008).

Seperti yang telah dikemukakan sebelumnya, bahwa pengungkapan sukarela merupakan suatu pengungkapan atas informasi yang melebihi syarat minimum atas standar pelaporan yang berlaku dan sifatnya tidak wajib. Pengungkapan sukarela pada bank syariah dapat berupa kebijakan akuntansi, rincian detail, penjelasan penting, dan komitmen yang terkait dengan manajemen. Sifatnya yang tidak wajib (voluntary) membuat manajemen perusahaan akan melakukan pertimbangan mengenai manfaat dan biaya yang timbul dari pengungkapan sukarela. Dengan adanya pengungkapan sukarela diharapkan dapat memenuhi ketersediaan informasi yang dibutuhkan bagi pihak-pihak berkepentingan. Artinya meskipun tidak bersifat wajib dan tidak ada pihak yang berwenang dalam mengatur tentang pengungkapan sukarela, namun dengan adanya signalling theory, manajemen akan memberikan sinyal berupa informasi tambahan yang berdasarkan pertimbangannya dapat mempengaruhi keputusan stakeholder.

Pengungkapan sukarela yang dilakukan oleh perusahaan juga ditujukan untuk mengendalikan konflik kepentingan antara pemegang saham, kreditur, dan manajemen. Hal ini dapat dijelaskan dalam teori keagenan (Agency Theory). Teori tersebut menjelaskan hubungan antara pemilik (Principal) dan pengelola perusahaan atau manajemen sebagai agen yang nantinya memberikan publikasi atas laporan tahunan perusahaan sebagai wujud pertanggung jawaban kepada principal untuk meminimalisir terjadinya asimetri informasi (Vernando, 2016).

Penelitian tentang pengungkapan sukarela bukan suatu hal baru, banyak penelitian sebelumnya yang mengangkat tema serupa dengan objek dan waktu penelitian yang berbeda. Penelitian tersebut sebagian besar mencoba untuk melihat berbagai faktor yang mendorong suatu perusahaan untuk melakukan pengungkapan sukarela. Beberapa variabel yang digunakan sebagai faktor pendorong perusahaan untuk melakukan pengungkapan sukarela seperti dalam penelitian Wardani (2012) diantaranya adalah ukuran perusahaan, leverage, porsi kepemilikan saham, likuiditas, profitabilitas, serta umur perusahaan. Bank syariah tidak luput dari penelitian serupa, berbagai pemicu yang diduga menjadi alasan yang mendorong dilakukannya pengungkapan sukarela telah banyak dikemukakan.

Ownership dispersion merupakan salah satu faktor yang mempengaruhi luas pengungkapan sukarela suatu perusahaan (Hardiningsih, 2008 dan Indriani et al., 2014). Ownership dispersion adalah pembagian porsi kepemilikan saham perusahaan yang dimiliki oleh publik. Semakin banyak pemegang saham menunjukkan semakin banyak pihak-pihak yang berkepentingan dalam perusahaan tersebut, sehingga semakin besar pula tekanan yang dihadapi perusahaan untuk mengungkapkan informasi. Ownership dispersion pada bank 
syariah masih terbilang rendah, hal ini dapat terlihat dari jumlah bank syariah yang melepas sahamnya ke publik. Dari total 14 bank syariah yang terdaftar di OJK, hanya terdapat 3 bank syariah yang dimiliki sahamnya oleh publik. Dengan demikian, pengungkapan sukarela lebih banyak dilakukan oleh bank syariah yang kepemilikan sahamnya dimiliki oleh publik.

Dalam penelitian yang dilakukan Hardiningsih (2008) menunjukkan proporsi kepemilikan saham publik berpengaruh signifikan terhadap luas pengungkapan sukarela. Artinya proporsi kepemilikan saham oleh publik akan mendorong perusahaan untuk lebih dalam melakukan pengungkapan sukarela agar publik mendapatkan gambaran yang jelas tentang perusahaan, baik secara keuangan dan non keuangan. Hal serupa diungkapkan pula dalam penelitian yang dilakukan oleh Vernando \& Halmawati (2016) dan Delvinur (2015). Namun, hasil yang berbeda diungkapkan dalam penelitian yang dilakukan oleh Benardi et. al. (2009), Wardani (2012), dan Cahyowati (2018) yang menunjukkan ownership dispersion tidak berpengaruh terhadap luas pengungkapan sukarela.

Faktor lain yang diprediksi mempengaruhi luas pengungkapan sukarela adalah Financial Distress. Financial distress merupakan suatu kondisi di mana perusahaan memiliki kesulitan untuk memenuhi kewajiban yang dimiliki kepada pihak pemberi pinjaman (creditor) atau sebuah indikasi ketika perusahaan tersebut melakukan restrukturisasi utang yang disebabkan oleh kesulitan dalam membayar kewajiban yang dimiliki (Andrade \& Kaplan, 2008 dalam Vernando \& Halmawati, 2016). Kondisi ini dapat terjadi pada suatu bank jika tidak melakukan pengukuran tingkat kesehatannya. Untuk itu, bank syariah perlu melakukan pengukuran tingkat kesehatan agar dapat memprediksi potensi kebangkrutan yang akan terjadi. Kemungkinan besar perusahaan yang sedang menghadapi ketidakpastian tinggi atas pendapatan masa depan akan melaporkan balance sheet disclosures. Hal ini juga diperkuat dengan pernyataan Holder-Webb (2002) yang menemukan pada tahun perusahaan mengalami kondisi distress, semua perusahaan meningkatkan pengungkapan mereka. Lebih lanjut, Webb \& Cohen (2007) juga menemukan rata-rata manajer perusahaan yang sedang mengalami financial distress akan meningkatkan kualitas pengungkapan mereka. Temuan-temuan tersebut juga diperkuat dengan keberadaan signaling theory yang menyatakan apabila perusahaan sedang dalam keadaan yang baik, perusahaan akan dengan sukarela memberikan signal kepada para investornya (Watson, Shrives, \& Marston, 2002). Lebih lanjut, dengan kehadiran multiple audiences, para manajer mungkin berkeinginan untuk mengungkapkan berita buruk walaupun berseberangan dengan kehendaknya untuk meningkatkan ekspektasi para investor, karena adanya konflik kehendak untuk melemahkan ekspektasi audiensi yang lain (Einhorn, 2007).

Hasil penelitian Holder-Webb (2002) berbeda dengan Teoh \& Hwang (1990), serta Nasir \& Abdullah (2004). Teoh \& Hwang (1990) menemukan, perusahaan berkualitas tinggi tidak akan mengungkapkan berita buruk bila ada, serta perusahaan berkualitas rendah sangat memilih tidak melaporkan kecuali berita baik. Selanjutnya, Nasir \& Abdullah (2004) menemukan perusahaan yang sedang dalam kondisi financially distress cenderung untuk mengungkapkan informasi yang lebih sedikit dibandingkan perusahaan yang sehat. Berdasarkan 
perbedaan pendapat tersebut, peneliti tertarik untuk melihat pengaruh kondisi financial distress pada voluntary disclosure.

Selanjutnya, faktor yang diprediksi mempengaruhi luas pengungkapan sukarela adalah umur listing perusahaan (Wardani, 2012; Indriani et al., 2014). Umur listing perusahaan merupakan seberapa lama perusahaan terdaftar di Bursa Efek Indonesia sebagai perusahaan go public. Semakin lama perusahaan menjadi perusahaan publik, maka diharapkan perusahaan semakin mengetahui kebutuhan informasi para penggunanya atau semakin mengetahui kebutuhan informasi para stakeholder perusahaan, sehinga perusahaan akan berusaha memenuhi kebutuhan informasi para stakeholder melalui pengungkapan informasi sukarela yang diungkapkan dalam laporan tahunan sebagai alat untuk pengawasan kinerja perusahaan agar kelangsungan usaha perusahaan tetap terjaga (Wardani, 2012).

Secara implisit, semakin lama umur perusahaan maka perusahaan akan lebih mempunyai pengalaman dan pengetahuan atas apa saja yang perlu diungkapkan dalam pengungkapan sukarela. Perusahaan yang memiliki umur lebih tua memiliki lebih banyak pengalaman dalam mempublikasi laporan tahunan peusahaan. Beberapa penelitian terdahulu mengenai faktor-faktor yang serupa dengan peneliti terkait luas pengungkapan sukarela diantaranya adalah Indriani et al., (2014) yang meneliti variabel porsi kepemilikan saham publik, umur listing, likuiditas dan ukuran KAP. Hasil penelitiannya adalah porsi kepemilikan saham publik berpengaruh positif terhadap luas pengungkapan sukarela dan likuiditas berpengaruh negatif terhadap luas pengungkapan sukarela. Sedangkan umur listing dan ukuran KAP tidak berpengaruh terhadap luas pengungkapan sukarela.

Penelitian Gantyowati \& Nugraheni, (2014) meneliti pengaruh financial distress dan struktur Corporate Governance terhadap voluntary disclosure. Financial Distress, independensi dewan komisaris, jumlah rapat dewan komisaris, independensi komite audit, jumlah rapat komite audit dan institutional ownership digunakan sebagai variabel yang mempengaruhi voluntary disclosure. Hasil penelitian menujukan bahwa Financial Distress, independensi komite audit dan jumlah rapat komite audit berpengaruh signifikan terhadap voluntary disclosure, sedangkan independensi dewan komisaris, jumlah rapat dewan komisaris dan institutional ownership tidak berpengaruh signifikan. Penelitian Wardani (2012) menggunakan variabel ukuran perusahaan, leverage, Dispersion of ownership, likuiditas, profitabilitas, dan umur perusahaan. Hasil penelitiannya adalah ukuran perusahaan, profitabilitas, dan umur perusahaan berpengaruh terhadap luas pengungkapan sukarela.

Benardi, et al., (2009) mengukur pengaruh porsi kepemilikan saham publik, likuiditas, dan ukuran KAP (auditor) terhadap luas pengungkapan. Hasil penelitian menunjukkan bahwa ukuran KAP (auditor) berpengaruh terhadap luas pengungkapan, sedangkan porsi kepemilikan saham publik dan likuiditas tidak berpengaruh. Delvinur (2015) meneliti pengaruh likuiditas dan proporsi kepemilikan saham publik terhadap luas pengungkapan sukarela pada perusahaan go public yang terdaftar di BEI tahun 2008-2012. Hasil penelitiannya menunjukkan proporsi kepemilikan saham berpengaruh terhadap luas pengungkapan sukarela, sedangkan likuiditas tidak berpengaruh. 
Penelitian tentang pengungkapan sukarela masih penting dilakukan karena sangat diperlukan dalam laporan tahunan oleh pihak-pihak pengguna khususnya stakeholder yaitu untuk menilai kinerja perusahaan dan memprediksi kinerja perusahaan di masa depan. Selain itu, pengungkapan sukarela dapat memberikan citra yang positif karena para pemakai laporan keuangan merasa mendapatkan informasi yang lebih luas (tidak ada yang disembunyikan) terkait dengan kondisi perusahaan.

Perbedaan penelitian ini dengan penelitian terdahulu yakni adanya penggunaan variabel Financial Distress yang diduga mempengaruhi pengungkapan sukarela pada bank syariah dengan proksi Interest coverage ratio (Rasio antara laba operasional terhadap biaya bunga) kurang dari satu. Umumnya penelitian terhadap variabel financial distress lebih banyak pada perusahaan manufaktur atau bank konvensional.

Berdasarkan uraian pada latar belakang di atas, serta adanya ketidak konsistenan penelitian sebelumnya. Penulis termotivasi untuk melakukan penelitian ini dengan judul "Pengaruh Ownership Dispersion, Financial Distress, Dewan Pengawas Syariah dan Umur Listing terhadap Luas Pengungkapan Sukarela". Perbedaan dengan penelitian sebelumnya, selain dari ketidak konsistenan hasil penelitian juga karena perbedaan objek yakni bank syariah yang terdaftar di OJK untuk periode laporan 2015 - 2018.

Perumusan hipotesis berdasakan rancangan penelitian yang dibuat dengan mengacu pada konsep teori yang digunakan dan didukung dengan penelitian terdahulu. Rancangan penelitian yang dibuat sebagai berikut:

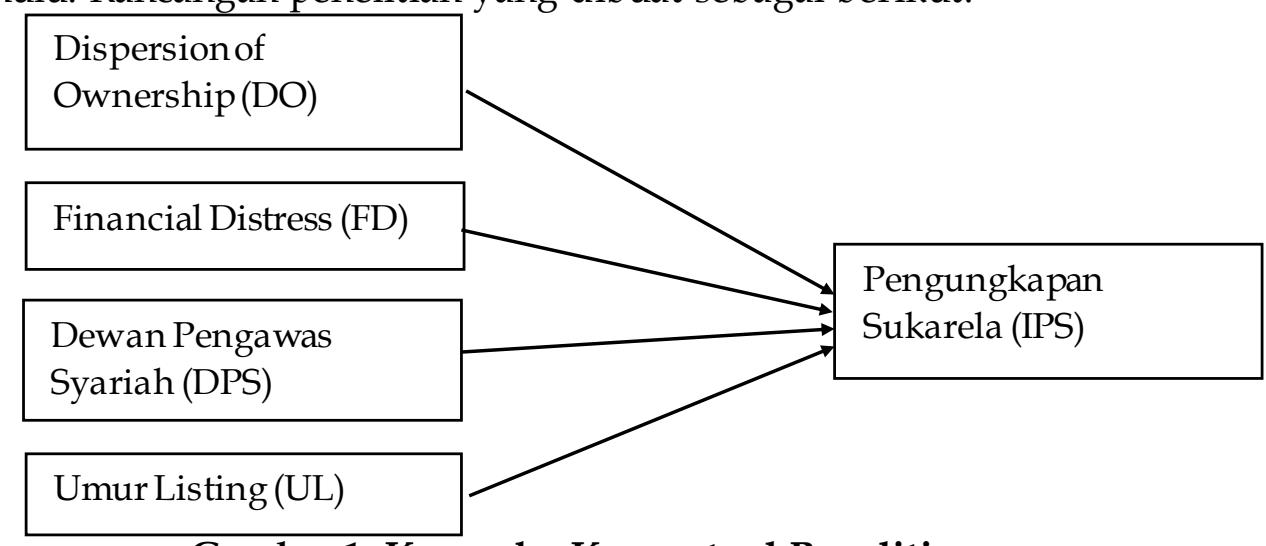

Sumber: Data Penelitian, 2018

\section{Gambar 1. Kerangka Konseptual Penelitian}

Dispersion of ownership adalah pembagian porsi kepemilikan saham perusahaan yang dimiliki oleh publik. Dimana tingkat pengungkapan informasi antar perusahaan mungkin berbeda dalam hal menanggapi proporsi kepentingan pemegang saham. Menurut Jensen dan Meckling (1976), biaya keagenan akan meningkat seiring dengan besarnya nilai saham yang beredar yang sangat erat kaitannya dengan proporsi kepemilikan terhadap perusahaan. Pancawati (2008) menunjukkan proporsi kepemilikan saham publik berpengaruh signifikan terhadap luas pengungkapan sukarela. Artinya proporsi kepemilikan saham oleh publik akan mendorong perusahaan untuk lebih dalam melakukan pengungkapan sukarela agar publik mendapatkan gambaran yang jelas tentang perusahaan, baik secara keuangan dan non keuangan. Hal serupa diungkapkan 
pula dalam penelitian yang dilakukan oleh Yuliansyah dan Yenny (2007), Wijayanti (2009), dan Erna, et al (2014). Dengan demikian, semakin banyaknya kepemilikan saham oleh publik, maka perusahaan melakukan pengungkapan yang lebih luas karena berhubungan dengan kepercayaan publik terhadap perusahaan. Maka hipotesis pertama dirumuskan sebagai berikut.

$\mathrm{H}_{1}$ : Dispersion of Ownership berpengaruh positif terhadap Luas Pengungkapan Sukarela.

Financial distress merupakan suatu kondisi di mana perusahaan memiliki kesulitan untuk memenuhi kewajiban yang dimiliki kepada pihak pemberi pinjaman (creditor) atau sebuah indikasi ketika perusahaan tersebut melakukan restrukturisasi utang yang disebabkan oleh kesulitan dalam membayar kewajiban yang dimiliki (Andrade dan Kaplan, 2008). teori keagenan (agency theory) menyatakan bahwa perusahaan yang mengalami kondisi kesulitan keuangan (financial distress) akan menyajikan informasi lebih kepada public dengan tujuan untuk mengurangi beban yang akan terjadi di masa depan dan menghindari terjadinya kebangkrutan (Gantyowati dan Nugraheni, 2014). Hal tersebut didukung oleh penelitian yang dilakukan oleh Wijantini; Webb dan Cohen (dalam Gantyowati dan Nugraheni, 2014). Dengan demikian, hipotesis penelitian ini yaitu:

$\mathrm{H}_{2}$ : Financial Distress berpengaruh positif terhadap luas pengungkapan sukarela.

Pada umumnya bank syariah lebih membutuhkan praktik good corporate governance daripada bank konvensional, karena bank syariah mempunyai potensi masalah agensi lebih besar daripada bank konvensional, dimana bank syariah bukan saja berhadapan dengan target meningkatkan modal pemilik saham, tetapi juga bank syariah harus memastikan bahwa setiap transaksi yang ia lakukan sesuai dengan kepatuhan syariah. (Archer et al., 1998). Penelitian yang dilakukan oleh Chapra dan Ahmed (2008) membuktikan bahwa kepatuhan pada syariah merupakan faktor yang penting, terbukti dari hasil penelitiannya yang mengungkapkan bahwa depositor bank syariah di Negara Bahrain dan Sudan mau menarik depositonya bila terbukti bank melakukan tindakan yang melanggar syariat. Rahman dan Bukair (2013) membuktikan bahwa ukuran dewan pengawas syariah berpengaruh positif terhadap tingkat pengungkapan Corporate Social Responsibility. Farook et. al. (2011) juga membuktikan bahwa ukuran dewan pengawas syariah berpengaruh positif terhadap tingkat pengungkapan Corporate Social Responsibility. Selain itu, penelitian tentang pengaruh dewan pengawas syariah terhadap pengungkapan juga pernah dilakukan oleh Abdullah et. Al. (2015) yang membuktikan bahwa ukuran dewan pengawas syariah berpengaruh positif terhadap tingkat pengungkapan corporate governance. Dengan demikian, hipotesis yang dibuat yaitu:

$\mathrm{H}_{3}$ : Dewan Pengawas Syariah berpengaruh positif terhadap luas pengungkapan sukarela.

Hubungan umur perusahaan dengan luas pengungkapan dapat diasumsikan bahwa semakin lama perusahaan menjadi perusahaan publik maka diharapkan perusahaan semakin memahami kebutuhan informasi yang dibutuhkan oleh pihak- pihak berkepentingan. Albitar (2015) menyatakan bahwa perusahaan yang lebih tua melakukan pengungkapan sukarela lebih luas dibandingkan perusahaan yang lebih muda. Penelitian oleh Puruwita (2012) 
menunjukkan bahwa umur listing berpengaruh terhadap luas pengungkapan sukarela perusahaan, alasannya bahwa perusahaan yang lebih tua mungkin lebih mengerti informasi apa saja yang sebaiknya diungkapkan dalam laporan tahunan. Perusahaan yang lebih lama beroperasi akan menyediakan publisitas informasi yang lebih luas dan lebih banyak dibandingkan dengan perusahaan yang baru berdiri. Maka, hipotesis keempat penelitian adalah sebagai berikut. $\mathrm{H}_{4}$ : Umur Listing berpengaruh positif terhadap Luas Pengungkapan Sukarela.

\section{METODE PENELITIAN}

Pengukuran variable menggunakan berapa banyak item pengungkapan laporan tahunan yang diungkapkan oleh bank umum syariah. Item pengungkapan sukarela ini berjumlah 80 item yang diambil dari item penilaian Annual Report Award 2015 (Ali \& Lbs, 2015) dan telah disesuaikan dengan item pengungkapan wajib di Indonesia yakni Surat Edaran OJK Nomor 18/SEOJK.03/2015 Tentang Transparansi dan Publikasi Laporan Bank Umum Syariah (BUS) Dan Unit Usaha Syariah (UUS). Indeks Pengungkapan Sukarela (IPS) untuk setiap perusahaan sampel diperoleh dengan cara sebagai berikut : Memberi skor untuk setiap item pengungkapan secara dikotomi, jika suatu item diungkapkan maka diberi nilai 1 dan jika tidak diungkapkan diberi nilai 0 . Skor yang diperoleh setiap perusahaan kemudian dijumlahkan untuk mendapatkan skor total atas pengungkapan sukarela. Indeks Pengungkapan Sukarela (IPS) didapatkan dengan membandingkan skor total yang diperoleh masing-masing perusahaan dengan skor total yang diharuskan untuk diungkapkan dalam laporan tahunan.

Formula yang digunakan untuk mencari skor indeks penungkapan adalah sebagai berikut (Ali \& Lbs, 2015):

$$
\text { IPS }=\frac{\text { Total item Pengungkapan }}{\text { Skor maksimum pengunkapan }(80 \mathrm{item})} \times 100 \%
$$

Keterangan:

IPS $\quad=$ Indeks pengungkapan sukarela

Total pengungkapan $=$ Jumlah skor yang diperoleh dari pengungkapan perusahaan

Skor maksimum = Jumlah nilai maksimum pengungkapan

Komponen penilaian ini diadopsi dari item penilaian Annual Report Award 2015.

Dispersion of ownership adalah ratio jumlah pemegang saham biasa dengan jumlah saham yang beredar. Dispersion of ownership diukur berdasarkan log natural jumlah pemegang saham biasa (Putra, 2006) dengan rumus :

Dispersion of ownership $=$ LnJumlah Pemegang Saham Biasa......(2)

Perusahaan yang mengalami kondisi financial distress (DISTRS) adalah perusahaan yang tidak mampu untuk membayar liabilitas yang dimiliki perusahaan tersebut. Pengukuran financial distress dalam penelitian ini mengacu pada penelitian Classens et al. (1999) dalam Vernando \& Halmawati (2016) yang menggunakan interest coverage ratio (rasio antara laba operasional terhadap biaya bunga) untuk mendefinisikan distressed. Perusahaan yang berada dalam financial distress adalah perusahaan yang memiliki interest coverage ratio (rasio antara laba operasional terhadap biaya bunga) kurang dari satu. 
Dewan pengawas syariah memiliki fungsi penting dalam hal pengawasan prinsip syariah di suatu bank syariah, dimana dewan pengawas syariah bertugas memberi nasihat serta saran kepada dewan direksi ataupun pimpinan kantor cabang mengenai hal-hal yang berkaitan dengan aspek syariah. Dewan pengawas syariah dihitung dengan menjumlahkan seluruh anggota dewan pengawas syariah yang ada di bank yang diteliti (Mediawati dan Afiyana, 2018). Dewan pengawas syariah adalah dewan pengawas syariah yang dihitung dengan menjumlahkan seluruh anggota dewan pengawas syariah yang ada di bank yang diteliti.

Umur Listing perusahaan diukur dengan seberapa lama perusahaan terdaftar di Bursa Efek Indonesia sebagai perusahaan go public sampai dengan tahun pengambilan sampel. Umur listing perusahaan diukur dengan menghitung umur perusahaan sejak tanggal awal listing di Bursa Efek Indonesia sampai dengan tahun penelitian yang digunakan (Erna, 2014).

Jenis dan sumber data dalam penelitian ini adalah data sekunder yang merupakan sumber data penelitian yang diperoleh secara tidak langsung melainkan melalui media perantara. Data sekunder tersebut diperoleh dari laporan tahunan Bank Umum Syariah (BUS) yang terdaftar di OJK (Otoritas Jasa Keuangan) pada tahun 2015-2018. Populasi yang digunakan dalam penelitian ini sebanyak 14 perusahaan yang termasuk dalam kategori perusahaan BUS. Teknik pengambilan sampel dengan metode purposive sampling. Adapun karakteristik sampel yang digunakan dalam memilih sampel penelitian ini disajikan dalam tabel sebagai berikut:

Tabel 1. Karakteristik Sampel

\begin{tabular}{llll}
\hline No & Kriteria & Jumlah Perusahaan \\
\hline 1 & $\begin{array}{l}\text { Perusahaan yang termasuk dalam kategori } \\
\text { perusahaan Bank UmumSyariah(BUS) yang terdaftar } \\
\text { di Otoritas Jasa Keuangan (OJK) per Desember 2018 }\end{array}$ & 14 \\
2 & $\begin{array}{l}\text { Perusahaan Bank Umum Syariah (BUS) yang tidak } \\
\text { menyajikan laporan tahunan denganlengkap periode }\end{array}$ & $(1)$ \\
2015-2018 & 13 \\
\hline Jumlah sampel perusahaan BUS yang digunakan &
\end{tabular}
Sumber: Data Penelitian, 2018

Berdasarkan kriteria sampel yang digunakan, terdapat 13 Bank Umum Syariah (BUS) yang memenuhi kriteria sampel dalam penelitian ini dengan periode pengamatan selama 4 tahun (periode 2015-2018) sehingga jumlah data pengamatan sebanyak $4 \times 13=52$ data pengamatan.

Prosedur analisis data yang digunakan dalam penelitian ini terdiri dari analisis statistik deskriptif, uji asumsi klasik dan pengujian hipotesis. Penelitian ini menggunakan model analisis regresi linier berganda. dengan model dasar sebagai berikut :

$$
\mathrm{IPS}=\beta_{0}+\beta 1 \mathrm{DO}+\beta 2 \mathrm{FD}+\beta 3 \mathrm{DPS}+\beta 4 \mathrm{UL}+\varepsilon
$$

Keterangan:

$$
\begin{array}{lll}
\beta & =\text { Koefisien Regresi } & \text { IPS }=\text { Indeks pengungkapan } \\
& \text { sukarela } & \\
\varepsilon & =\text { kesalahan pengganggu } & \mathrm{UL}=\text { Umur Listing Perusahaan } \\
\text { DO } & =\text { Dispersion of ownership } & \text { FD }=\text { Financial distress }
\end{array}
$$


DPS = Jumlah dewan pengawas syariah

\section{HASIL DAN PEMBAHASAN}

Melihat hasil output pada Tabel 3 menunjukkan bahwa nilai tolerance terkecil sebesar 0.496. artinya tidak ada variabel independen yang memiliki nilai tolerance kurang dari 0.10. Dengan demikian, tidak ada korelasi antar variabel independen yang nilainya lebih dari $95 \%$.

Tabel 2. Hasil Uji Multikolonieritas Dengan Nilai Tolerance dan VIF

\begin{tabular}{llll}
\hline \multirow{2}{*}{ Model } & & \multicolumn{2}{c}{ Collinearity Statistics } \\
\cline { 3 - 4 } & & Tolerance & VIF \\
& (Constant) & & \\
& OD & .657 & 1.521 \\
& FD & .935 & 1.070 \\
& DPS & .599 & 1.670 \\
& UL & .496 & 2.244 \\
\hline
\end{tabular}

a. Dependent Variable: IPS

Sumber: Data Penelitian, 2018

Hasil perhitungan nilai VIF juga menunjukkan hal yang sama bahwa nilai VIF tertinggi sebesar 2.244 masih lebih kecil dari 10 yang berarti tidak ada satu variabel independen yang memiliki nilai VIF lebih dari 10. Jadi dapat disimpulkan bahwa tidak ada multikolonieritas antar variabel independen dalam model regresi yang dibuat.

Tabel 3. Hasil Uji Normalitas

\begin{tabular}{|c|c|c|}
\hline \multicolumn{3}{|c|}{ One-Sample Kolmogorov-Smirnov Test } \\
\hline & & Unstandardized Residual \\
\hline$\overline{\mathrm{N}}$ & & $\mathrm{Cl}_{\mathrm{C}}$ \\
\hline \multirow[t]{2}{*}{ Normal Parameters ${ }^{a}$} & Mean & .0000000 \\
\hline & Std. Deviation & 1.27813207 \\
\hline \multicolumn{2}{|c|}{ Kolmogorov-Smirnov Z } & 1.336 \\
\hline \multicolumn{2}{|c|}{ Asymp. Sig. (2-tailed) } & .156 \\
\hline \multicolumn{3}{|c|}{ a. Test distribution is Normal. } \\
\hline
\end{tabular}

Sumber: Data Penelitian, 2018

Pada Tabel 3. dapat diketahui bahwa nilai Kolmogorov-Smirnov sebesar 1.336 dan tingkat probabilitas signifikansi diatas 0.05 yaitu sebesar 0.156 . hal ini mengindikasikan bahwa data residual terdistribusi secara normal.

Tabel 4. Hasil Uji Koefisien Determinasi

\begin{tabular}{lll}
\hline Model & Adjusted $R$ Square & Std. Error of the Estimate \\
\hline 1 & .642 & 1.3314102 \\
\hline a. Predictors: (Constant), UL, FD, OD, DPS &
\end{tabular}

Sumber: Data Penelitian, 2018

Tabel 4. menunjukkan besarnya nilai Adjusted R Square sebesar 0,642. Nilai ini menerangkan besarnya peran atau kontribusi variabel independen dispersion of ownership, financial distress, dewan pengawas syariah dan umur listing yang mampu menjelaskan pengungkapan sukarela sebesar 0,642 atau 
$64,2 \%$ sedangkan 35,8\% dijelaskan oleh variabel diluar model. Nilai Standard Error of the Estimate (SEE) yang kecil yaitu sebesar 1,331 membuat model regresi ini tepat digunakan dalam memprediksi variabel dependen.

Tabel 5. Hasil Uji F

\begin{tabular}{llll}
\hline Model & & ANOVA $^{\mathrm{b}}$ & \\
\hline 1 & $\mathrm{~F}$ & Sig. \\
\hline & $\begin{array}{l}\text { Regression } \\
\text { Residual } \\
\text { Total }\end{array}$ & 8.234 & $.000^{\mathrm{a}}$ \\
& & & \\
\hline
\end{tabular}

a. Predictors: (Constant), UL, FD, OD, DPS

b. Dependent Variable: IPS

Sumber: Data Penelitian, 2018

Output hasil uji statistik F yang terdapat dalam Tabel 6. diperoleh nilai F hitung sebesar 8,234 dan signifikan pada 0,000. Karena probabilitas jauh lebih kecil dari 0,05, maka model regresi dapat digunakan untuk memprediksi variabel dependen.

Tabel 6. Hasil Uji t

Coefficients $^{a}$

\begin{tabular}{llll} 
& & \multicolumn{2}{c}{ Standardized Coefficients } \\
\cline { 3 - 4 } Model & & Beta & Sig. \\
\hline 1 & (Constant) & .199 & .001 \\
& OD & .232 & .156 \\
& FD & -.240 & .041 \\
DPS & .566 & .104 \\
& UL & & .001 \\
\hline
\end{tabular}

a. Dependent Variable: IPS

Sumber: Data Penelitian, 2018

Berdasarkan hasil perhitungan pada Tabel 7. dapat diketahui hasil pengujian hipotesis yaitu nilai signifikansi OD terhadap IPS sebesar 0,156 (lebih besar dari 0,05) dan nilai koefisien beta sebesar 0,199 yang berarti OD tidak berpengaruh terhadap IPS. Dengan demikian hipotesis pertama yang menyatakan ownership dispersion berpengaruh terhadap pengungkapan sukarela tidak diterima.

Nilai signifikansi FD sebesar 0,041 (lebih kecil dari 0,05) artinya FD berpengaruh signifikan terhadap pengungkapan sukarela dan pengaruhnya positif dapat dilihat dari nilai koefisien beta sebesar 0,232. Berarti dapat disimpulkan bahwa hipotesis kedua yang menyatakan financial distress berpengaruh terhadap pengungkapan sukarela dapat diterima.

Nilai signifikansi DPS terhadap pengungkapan sukarela sebesar 0,104 (lebih besar dari 0,05) dan nilai koefisien beta sebesar -0,240 yang berarti DPS tidak berpengaruh terhadap pengungkapan sukarela. Dengan demikian hipotesis ketiga yang menyatakan dewan pengawas syariah berpengaruh terhadap pengungkapan sukarela gagal untuk diterima. 
Nilai signifikansi UL sebesar 0,001 (lebih kecil dari 0,05) artinya UL berpengaruh signifikan terhadap pengungkapan sukarela dan pengaruhnya positif. Hal ini dapat dilihat dari nilai koefisien beta sebesar 0,566. Berarti dapat disimpulkan bahwa hipotesis keempat yang menyatakan umur listing berpengaruh terhadap pengungkapan sukarela dapat diterima.

Dari hasil uji hipotesis dapat dibuat persamaan matematis sebagai berikut:

IPS $=0,199 \mathrm{OD}+0,232 \mathrm{FD}-0,24 \mathrm{DPS}+0,566 \mathrm{UL}+0,538 \varepsilon_{1}$

Hasil uji hipotesis diperoleh bukti bahwa Dispersion of ownership tidak berpengaruh terhadap pengungkapan sukarela. Jika kita mengacu pada data yang ada, bahwa sebagian besar data sampel untuk variabel ini mempunyai nilai rata-rata sebesar 1,5\%. Artinya dari 13 data Bank Umum Syariah, sebagian besar sahamnya milik sendiri dan hanya sedikit yang beredar kemasyarakat (publik). Dengan demikian tekanan dalam pengunkapan sukarela perusahaan kurang tinggi. Pada umumnya kepemilikan saham yang dimiliki oleh publik merupakan investor kecil, sehingga kurang bisa memberikan tekanan terhadap perusahaan dalam hal pengungkapan sukarela. Hal tersebut sejalan dengan penelitian yang dilakukan oleh Suta dan Laksito (2012) dalam Cahyowati (2018) yang menyatakan bahwa investor publik pada umumnya merupakan investor kecil atau investor dengan kepemilikan saham di bawah 5\%, sehingga kekuasaanya dianggap tidak banyak mempengaruhi atau tidak dapat melakukan tawar menawar yang seimbang dalam mengatur kebijakan manajemen perusahaan termasuk mengenai pengungkapan informasi. Alasan lainnya yaitu kepemilikan saham publik merupakan gabungan dari beberapa pemegang saham retail (skala kecil) dimana mereka kurang bisa menjalankan fungsi monitoring dan tidak bisa terlalu menekan ke perusahaan dalam kaitannya dengan pengungkapan informasi. Selain hasil penelitian Cahyowati (2018), hasil penelitian ini juga sejalan dengan penelitian oleh Benardi et al. (2009). Menurutnya, porsi kepemilikan saham oleh publik tidak berpengaruh terhadap luas pengungkapan sukarela adalah dikarenakan bahwa secara historis dan empiris perusahaanperusahaan publik di Indonesia mayoritas dikuasai oleh kalangan keluarga, sehingga manajer hanya menjadi kepanjangan tangan pemegang saham mayoritas (Benardi et al., 2009). Sedangkan alasan dari arah hubungan yang positif adalah bahwa perusahaan berusaha untuk memenuhi kepentingan para pemegang sahamnya sebagai bagian dari stakeholders yang berkepentingan terhadap kelangsungan usaha suatu perusahaan melalui pengungkapan laporan tahunan, dimana laporan tahunan merupakan alat pengawasan bagi pemegang saham sebagai bagian dari stakeholders terhadap kinerja manajemen. Hasil penelitian ini berbeda dengan hasil penelitian oleh Hardiningsih (2008), Indriani et al. (2014), Delvinur (2015) dan Vernando \& Halmawati (2016) yang menunjukkan proporsi kepemilikan saham publik berpengaruh signifikan terhadap luas pengungkapan sukarela. Artinya proporsi kepemilikan saham oleh publik akan mendorong perusahaan untuk lebih dalam melakukan pengungkapan sukarela agar publik mendapatkan gambaran yang jelas tentang perusahaan, baik secara keuangan dan non keuangan.

Hasil uji hipotesis diperoleh bukti bahwa Financial distress berpengaruh terhadap pengungkapan sukarela. Artinya bahwa meskipun Bank Umum Syariah dalam posisi Financial distress namun perusahaan tersebut tetap 
konsisten dalam mengungkapkan informasi yang dibutuhkan oleh stakeholder. Teori keagenan (agency theory) yang menyatakan bahwa perusahaan yang mengalami kondisi kesulitan keuangan (financial distress) akan menyajikan informasi lebih kepada public dengan tujuan untuk mengurangi beban yang akan terjadi di masa depan dan menghindari terjadinya kebangkrutan (Gantyowati dan Nugraheni, 2014). Ketika suatu perusahaan berada dalam kondisi kesulitan keuangan (financial distress), maka manajemen perusahaan akan sangat berhatihati dalam menyampaikan informasi yang akan di sampaikan.

Hasil uji hipotesis membuktikan bahwa variabel Dewan Pegawas Syariah (DPS) tidak berpengaruh terhadap pengungkapan sukarela Bank Umum Syariah diindonesia. Berdasarkan Undang-Undang Republik Indonesia No.21 tahun 2008 tentang Perbankan Syariah yang berisi bahwa setiap Bank Umum Syariah wajib memiliki Dewan Pengawas Syariah yang bertugas memberikan nasihat dan saran kepada Direksi serta mengawasi kegiatan Bank agar sesuai dengan prinsip syariah, mengawasi kegiatan usaha lembaga keuangan syariah agar sesuai dengan ketentuan dan prinsip syariah yang telah difatwakan oleh Dewan Syariah Nasional Majelis Ulama Indonesia (DSN MUI). Alasan DPS tidak berpengaruh terhadap pengungkapan sukarela karena jika mengacu dengan isi Undang-undang tersebut dapat diketahui bahwa DPS berwenang terhadap kegiatan operasional dan jenis produk Bank Umum Syariah, apakah sudah sesuai dengan prinsip syariah. Namun DPS tidak bisa menekan kegiatan pihak manajemen perusahaan termasuk dalam mengatur pengungkapan sukarela dalam laporan tahunan Bank Umum Syariah (BUS). Pada umumnya bank syariah lebih membutuhkan praktik good corporate governance daripada bank konvensional, karena bank syariah mempunyai potensi masalah agensi lebih besar daripada bank konvensional, dimana bank syariah bukan saja berhadapan dengan target meningkatkan modal pemilik saham, tetapi juga bank syariah harus memastikan bahwa setiap transaksi yang ia lakukan sesuai dengan kepatuhan syariah. (Archer et al., 1998). Penelitian yang dilakukan oleh Chapra dan Ahmed (2008) membuktikan bahwa kepatuhan pada syariah merupakan faktor yang penting, terbukti dari hasil penelitiannya yang mengungkapkan bahwa depositor bank syariah di Negara Bahrain dan Sudan mau menarik depositonya bila terbukti bank melakukan tindakan yang melanggar syariat. Hasil penelitian ini sejalan dengan penelitian Yulianti (2016) yang menemukan bahwa DPS tidak berpengaruh terhadap pengungkapan sukarela suatu perusahaan. Sedangkan hasil yang berbeda dari penelitian Cahyowati (2018) yang menyatakan bahwa dewan pengawas berpengaruh terhadap pengungkapan sukarela suatu perusahaan. Lebih lanjut Rostiana \& Sukanta (2016) menyatakan bahwa yang menjadi tugas pokok dan perhatian utama dari dewan pengawas syariah adalah dalam hal kepatuhan terhadap prinsip syariah. Salah satu tugas dewan pengawas syariah antara lain mengawasi kegiatan menyalurkan dana zakat, infak, dan sedekah. Jadi tidak dapat dipungkiri bahwa dewan pengawas syariah dalam jumlah yang cukup banyak dengan beragam perspektif, pengalaman, kompetensi, baik dalam bidang perbankan dan keuangan, serta keahlian dalam hal hukum Islam akan membuat kinerja bank semakin efektif. Semakin baiknya peran dewan pengawas syariah dalam mengawasi segala aktifitas perbankan yang harus dijalankan didasarkan dengan 
prinsip-prinsip syariah, maka semakin baik pula kinerja dan output yang dihasilkan oleh perbankan syariah.

Hasil uji hipotesis diperoleh bukti bahwa umur listing berpengaruh terhadap pengungkapan sukarela. Artinya semakin lama umur suatu perusahaan maka pengungkapan yang dilakukan semakin tinggi dan lengkap dibandingkan dengan perusahaan yang lebih muda. Variabel ini merupakan yang paling besar pengaruhnya dari empat variabel independen, dengan koefisien sebesar 0,566. Hal ini dikarenakan hubungan umur perusahaan dengan luas pengungkapan dapat diasumsikan bahwa semakin lama perusahaan menjadi perusahaan publik maka diharapkan perusahaan semakin memahami kebutuhan informasi yang dibutuhkan oleh pihak-pihak berkepentingan. perusahaan yang lebih tua melakukan pengungkapan sukarela lebih luas dibandingkan perusahaan yang lebih muda. Wardani (2012), menunjukkan bahwa umur listing berpengaruh terhadap luas pengungkapan sukarela perusahaan, alasannya bahwa perusahaan yang lebih tua mungkin lebih mengerti informasi apa saja yang sebaiknya diungkapkan dalam laporan tahunan.

\section{SIMPULAN}

Penelitian ini bertujuan untuk mengetahui ada tidaknya pengaruh secara parsial dan simultan variable dispersion of ownership, financial distress, dewan pengawas syariah dan umur listing terhadap pengungkapan sukarela Bank Umum Syariah (BUS) yang terdaftar di OJK. Berdasarkan hasil pengolahan data yang dilakukan, maka dapat dihasilkan beberapa temuan penelitian yaitu Secara simultan, penelitian ini memberikan bukti empiris bahwa dispersion of ownership, financial distress, dewan pengawas syariah dan umur listing memiliki pengaruh positif dan signifikan terhadap pengungkapan sukarela Bank Umum Syariah. Secara parsial, penelitian ini memberikan bukti empiris bahwa dispersion of ownership tidak memiliki pengaruh signifikan terhadap pengungkapan sukarela Bank Umum Syariah. Secara parsial, penelitian ini memberikan bukti empiris bahwa financial distress memiliki pengaruh positif dan signifikan terhadap pengungkapan sukarela Bank Umum Syariah. Secara parsial, penelitian ini memberikan bukti empiris bahwa dewan pengawas syariah tidak memiliki pengaruh signifikan terhadap pengungkapan sukarela Bank Umum Syariah. Secara parsial, penelitian ini memberikan bukti empiris bahwa umur listing memiliki pengaruh positif dan signifikan terhadap pengungkapan sukarela Bank Umum Syariah.

Penelitian ini memiliki keterbatasan yang dapat diperbaiki pada penelitian selanjutnya. Keterbatasan yang harus dicermati dan saran terhadap keterbatasan untuk penelitian selanjutnya yaitu Bagi peneliti selanjutnya, disarankan untuk lebih memfokuskan pada penggunaan sampel yang lebih banyak ataupun pada sektor lain, dimana pada penelitian ini hanya terbatas pada lingkup sektor Bank Umum Syariah. Selanjutnya memperbanyak sampel penelitian juga melingkupi penambahan periode penelitian.

\section{REFERENSI}


Ali, M. H., \& Lbs, A. T. (2015). Analisis Pengungkapan Sukarela Pada Bank Umum Syariah di Indonesia. Jurnal Akuntansi dan Keuangan Islam Vol. 3, No. 1 (2015) .

Andhika, I. M. (2012). Kebijakan Dividen, Kepemilikan Managerial, Kepemilikan Institusional, Profitabilitas, dan Resiko Bisnis terhadap Kebijakan Hutang. Accounting Analysis Journal. .

Andi, Kartika dan Hersugondo. 2009. Faktor-Faktor yang Mempengaruhi Kelengkapan Pengungkapan Laporan Keuangan pada Perusahaan Manufaktur Terdaftar di Bursa Efek Indonesia". Eksplanasi Vol. 4 No. 7.

Andrade, G. dan S.N. Kaplan .2008. How Costly Is Financial (Not Economic) Distress? Evidence from Highly Struktur modal Transactions That Become Distressed. Journal of Finance 53, 1443-1493.

Belkaoui, A.R. 2011. Accounting Theory. Jakarta: Salemba Empat.

Benardi, Meliana et al. 2009. Faktor-faktor yang Memengaruhi Luas Pengungkapan dan Implikasinya Terhadap Asimetri Informasi (Studi Pada Perusahaan Sektor Manufaktur yang Go Public Di Bursa Efek Indonesia).

Cahyowati, U., \& Fitri, L. W. (2018). Analisis Penqaruh Likuiditas, Komite Audit, Dewan Komisaris Independen, Kepemilikan Saham Publik, Dan Cross Directorship Terhadap Tingkat Pengungkapan Sukarela (Studi Empiris Pada Perusahaan Pertambangan Yang Terdaftar Di Bursa Efek Indonesia Tahun 2014-2017) (Doctoral Dissertation, IAIN Surakarta).

Chapra, Umar M. \& Ahmed, Habib. 2008. Corporate Governance. Edisi terjemahan: lembaga keuangan syariah. Jakarta Timur: PT Bumi Aksara

Delvinur, D. (2015). Pengaruh Leverage, Likuiditas Dan Proporsi Kepemilikan Saham Publik Terhadap Luas Pengungkapan Sukarela Dalam Laporan Tahunan. Jurnal Akuntansi, 3(1).Fathi, Elloumi dan Gueyie, J.P. 2001. Financial Distress and Corporate Governance: An Empirical Analysis, Corporate Governance, Vol. 1, No. 1, hal.15-23

Firmansyah, Irman. 2013. Social Disclosure Perbankan Syariah Di Indonesia Dan Malaysia. ISSN: 1978-3116. Jurnal Ekonomi \& Bisnis Vol. 7, No. 3, November 2013 Hal. 163-172

Gantyowati, Evi \& Nugraheni, Rosa Lenna. 2014. The Impact of Financial Distress Status and Corporate Governance Structures on the Level of Voluntary Disclosure Within Annual Reports of Firms (Case Study of Non-financial Firms in Indonesia Over the Period of 2009-2011). Journal of Modern Accounting and Auditing, ISSN 1548-6583. April 2014, Vol. 10, No. 4, 389-403

Ghozali, Imam. 2007. Aplikasi Analisis Multivariate Dengan Program SPSS. Semarang: Badan Penerbit Universitas Diponegoro Semarang

Hardiningsih, Pancawati. 2008. Analisis Faktor-faktor yang Mempengaruhi Voluntary Disclosure Laporan Tahunan Perusahaan. ISSN: 1412-3126 Vol. 15, No.1 Jurnal Bisnis dan Ekonomi (JBE), Maret 2008, Hal. 67 - 79

Indriani, et al. 2014. Faktor-Faktor yang Mempengaruhi Luas Pengungkapan Sukarela dan Implikasinya Terhadap Asimetri Informasi. Artikel Ilmiah 
Kasih, A. M. (2017). Faktor-faktor yang mempengaruhi pengungkapan islamic social reporting (Bachelor's thesis, Jakarta: Fakultas Ekonomi dan Bisnis UIN Syarif Hidayatullah Jakarta).

Khairiah \& Fuadi, Raida. 2017. Faktor-faktor yang Mempengaruhi Pengungkapan Sukarela Dalam Laporan Tahunan (Studi Pada Perbankan Syariah Di Indonesia). Jumal Ilmiah Mahasiswa Ekonomi Akuntansi (JIMEKA) Vol. 2, No. 1, (2017) Halaman 63-72

MAKSI. 2010. Buku Pedoman Penulisan Tesis: Program Studi Magister Akuntansi Program Pascasarjana Universitas Mataram 2010-2011. Mataram: MAKSI FE Unram

Mardi. 2016. Faktor - Faktor Yang Mempengaruhi Nilai Perusahaan Melalui Corporate Social Responsibility (CSR). ISSN: 2302-8556. E-Jurnal Akuntansi Universitas Udayana Vol.26.2.Februari (2019): 1518-1544

Marharani, Amanda Kyka dan Yulianto, Agung. 2016. Faktor-faktor yang Mempengaruhi Tingkat Pengungkapan Islamic Social Reporting Pada Bank Syariah. ISSN 2252-6765 Accounting Analysis Journal 5 (1) (2016)

Nurhikmah, Febty.,dkk. 2018. Pengaruh Dewan Pengawas Syariah Dan Intellectual Capital Terhadap Pengungkapan Corporate Social Responsibility Dengan Kinerja Keuangan Sebagai Variabel Mediasi (Studi Empiris Perbankan Syariah Di Indonesia). MALIA: Journal of Islamic Banking and Finance (2018, Vol. 2 No. 2) 2654-8569 (E-ISSN)/2654-8577 (P-ISSN).

Panjaitan, Evi Meliana. 2016. Analisis Faktor-faktor yang Mempengaruhi Luas Pengungkapan Sukarela (Voluntary Disclosure) Dalam Laporan Tahunan (Studi Empiris Pada Perusahaan Sektor Industri Barang Konsumsi Yang Terdaftar Di Bursa Efek Indonesia Tahun 2012-2013). JOM Fekon, Vol. 3 No. 1 (Februari) 2016

Prastika, Nurhikmah Esti. 2016. Analisis Pengaruh Ukuran Bank Syariah, Profitabilitas Dan Leverage Terhadap Pengungkapan Laporan Keuangan Tahun 2006-2011 (Studi Empiris Pada Bank Syariah di Indonesia). Majalah neraca.

Rizfani, Khaerun nissa \& Lubis, Deni. 2018. Pengungkapan Islamic Social Reporting pada Perusahaan di Jakarta Islamic Index Disclosure of Islamic Social Reporting among Companies in Jakarta Islamic Index. Jurnal AlMuzara'ah Vol. 6 No. 2, 2018 (ISSN p: 2337-6333; e: 2615-7659) DOI: 10.29244/jam.6.2.103-116

Rostiani, Siti Sara \& Sukanta, Tuntun A. 2016. Pengaruh Dewan Pengawas Syariah, Profitabilitas Dan Leverage Terhadap Pengungkapan Islamic Social Reporting (ISR) (Studi Pada Bank Umum Syariah di Indonesia Periode 2012-2016). ISSN 2460-030X: Jurnal Akuntansi Bisnis dan Ekonomi Volume 4 No. 2, September 2018

Solihin, A.I. (2008). Ini Lho, Bank Syariah !. Jakarta: Grafindo.

Sugiyono. 2006. Metode Penelitian Bisnis. Bandung: CV. Alfabeta

Sugiyono. 2006. Metode Penelitian Kuantitatif Kualitatif dan RED. Bandung: CV. Alfabeta

Sugiyono. 2006. Metode Penelitian Pendidikan, Pendekatan Kuantitatif, Kualitatif dan $R \mathcal{E} D$. Bandung: Penerbit Alfabeta 
Suwardjono. 2005. Teori Akuntansi perekayasaan pelaporan keuangan. Yogyakarta : BPFE.

Thomas G. 2003. Accounting Theory : Contemporary Accounting Issue, USA : South Western

Triyuwono, Iwan. 2006. Perspektif, Metodologi, dan Teori Akuntansi Syariah. Jakarta: Rajawali Press

Vernando, Rahmat Yoga \& Halmawati. 2016. Pengaruh Ownership Dispersion, Financial Distressed, dan Umur Listing Terhadap Luas Pengungkapan Sukarela: Studi Empiris pada Perusahaan Manufaktur yang Terdaftar di BEI Tahun 2012-2014. Jurnal WRA, Vol 4, No 1, April 2016

Wardani, Rr. Puruwita. 2012. Faktor-Faktor yang Mempengaruhi Luas Pengungkapan Sukarela. Jurnal Akuntansi dan Keuangan, Vol. 14, NO. 1, MEI 2012: 1-15

Yulianti, N. (2016). Pengaruh Komposisi Dewan Komisaris, Efektivitas Komite Audit, Konsentrasi Kepemilikan, Financial Distress, dan Assets in Place Terhadap Penoungkapan Sukarela (Voluntary Disclosure) Dalam Laporan Tahunan: Studi Empiris pada Perusahaan Perbankan yang Terdaftar di Bursa Efek Indonesia Periode 2012-2014 (Bachelor's thesis, Jakarta: Fakultas Ekonomi dan Bisnis UIN Syarif Hidayatullah Jakarta).

Zahrah, P.M. (2012). Hukum Taklifi Dalam Ushul Fiqih. Jakarta: PT Pustaka Firdaus. 